\title{
Sindet $\mathrm{i}$ virkeligheden
}

\author{
Jakob Knudsens Sind
}

\section{JENS SMARUP SøRENSEN}

Så længe vi rigtig véd noget om dette land, har dets indbyggere $\mathrm{i}$ det store og hele jo ernæret sig ved landbrug. Indtil for nylig fortsatte det sådan, det var bønder der i deres ansigts sved sikrede et økonomisk grundlag også for købstædernes liv, det var bønder der gjorde det muligt at forsørge en embedsstand, at opretholde hær og flåde, at uddanne præster og læger, og det var naturligvis også bønder der skabte det overskud, der skulle til for at vi kunne udvikle en egen kunst og en national litteratur. Så meget desto mindre imponeret må man undre sig over at denne bondefinansierede litteratur så sjældent har forsøgt sig med at fremstille bønder som noget, der kunne minde om mennesker.

Et er vel at købstadsfolkene, borgerskabet, bureaukratiet og militæret og den lærde republik altid har tilladt sig at foragte bønderne, eller i heldigste fald måske blot fundet dem komiske. Det er også begribeligt at den arbejderklasse, som delvist og kortvarigt kom til at afløse bondestanden som samfundsbærende, men som i første omgang bare blev revet væk fra markernes lys og luft og anbragt i skumle fabrikker og baggårdslejligheder, at den straks følte trang til at kaste et mildere skær over livet på stenbroen ved at sværte den tabte fortid $\mathrm{i}$ det landlige. Det er jo derimod litteraturens vidtåbne mulighed og løbende forpligtelse at bekrige og at latterliggøre sådan nogle sociale fordomme. At udstille provinsielt hovmod og standsmæssig bornerthed, at gøre op med dumheden og med selvforherligende eller blot selvbeskyttende reduktioner af noget menneske i verden, om det så er en tysker, en sort, en parkeringsvagt eller altså en bonde. Den har dog alt for sjældent villet se ham i øjnene, vores danske litteratur. Den har ad- spredt udpeget ham som eksempel på almue og manglende dannelse, den har folkloristisk gjort brug af ham til borgerlige løjer og fædrelandsk pyntelighed, eller den har dæmoniseret og glorificeret ham i den ene eller den anden ideologiske hensigt.

Jakob Knudsen hævder sig som en af de forbløffende få der har villet, og jo ikke mindst kunnet skrive om bonden, så ingen læser med ham stilles over for en anden art end sin egen, og så enhver læser i ham kan genkende hele sig selv.

Romanen Sind udkom i r903. I en tid altså hvor der også hos andre var god gang i skildringen af bønder, men så_alligevel ikke_rigtig med_henblik påan_en_skil_ dring af mennesker som du og jeg. De skulle oftest optræde i mere specifikke versioner, hos Johan Skjoldborg som heroiske husmænd for eksempel, og som enfoldige fortidslevninger eller kyniske tyendetyranner hos Jeppe Aakjær, og som spøjse folkelivseller idealiserede urtyper hos Johs. V. Jensen, og så videre. Jakob Knudsen havde ingen af den slags instrumentelle særinteresser. Han var fuldkommen fri for nostalgi, politik og sociale fremskridt ragede ham (i bedste fald) en høstblomst, og han havde ingen ambitioner om at kreere sjove figurer til det litterære nationalalbum. Han var så meget mere brændende optaget af spørgsmålet om hvad et menneske er, og om hvordan et menneskeliv kan leves, og de mennesker han $\mathrm{i}$ virkeligheden kendte mest til beskæftigede sig - som jo stadig langt de fleste - med landbrug. Og så beherskede han som bekendt sit håndværk, og han udøvede det levende og stærkt, dramatisk og humoristisk, med en høj psykologisk og filosofisk intelligens. 
Det væsentligste af menneskesynet i Sind, i udforskningen af det, kommer frem - af sig selv, som man siger - i den bare handlingsgang. Vi er i Han Herred, da hovedpersonen Anders Hjarmsted endnu er dreng og yngling, og han er i konflikt med sin far og, forekommer det ham efterhånden, også med Fader Vor i himlen. Ham her på jorden er i hvert fald en hård negl. Han underkuer kone og børn, han ligger konstant $\mathrm{i}$ strid med naboer og øvrighed, han anser alle mennesker for 'kjæltringer' og viger ikke tilbage for at tage loven $i$ egen hånd, når myndighederne, atter en gang, har svigtet. Anders er med en aften hvor hans far med en jernstang slår en mand, der har ladet sine heste græsse på hans marker, halvt i smadder. Og det er stadig hans far, og drengen må beundre den brutale handlekraft, men den vækker også en snigende væmmelse $\mathrm{i}$ ham, en begyndende vrede. Han bliver mere og mere led ved at se sin mor og søster blive behandlet som slaver, og han fantaserer, idet han føler sig fortvivlet sikker på at Gud nu er ude af verden, om at slå sin far ihjel. Hans eneste og foreløbige redning er at komme væk. En smule at leve på får han endda med i rygsækken inden-afsk-eden:-faderens-skånselsløse-misantropi-viser sig for det første $\mathrm{i}$ særlig grad at gælde hans egen person, og for det andet er det da heller ikke denne ringe skabning han slås så djævelsk for, men for at der skal komme retfærdighed i verden.

Søndenfjords, i Himmerland er det vel, køber Anders Hjarmsted så, efter sin soldatertid og med penge fra sin far, en gård for med den for alvor at få taget hul på sit eget liv. Han vil først kunne føle det som sådant, før han vil lade faderen komme til sig, men den gamle er dog allerede med, i det indre, mærker Anders meget snart. Hadet til uretten mellem mennesker er - under hadet til faderen - groet dybt ind i ham. Og uretten er nok desværre mindst lige så udbredt her som den var i Han Herred, ja den dyrkes formelig som livsstil på den store nabogård Staun, hvor der ellers bor folk som er anderledes muntre og lyse i sindet, end nogen han for har mødt. Der hersker umiddelbart den dejligste stemning på Staun, alle er så afvæbnende frimodige og så hjerteligt elskværdige og altså - gennemfordærvede. De pløjer og sår som det passer dem på egnens gamle fællesjord, de lader deres kreaturer brede sig over alle græsningsarealer, og de gør det i en art troskyldig magtbrynde, som de dog hele tiden søger - slet ikke moralsk men - juridisk dækning for, gennem stærke bånd til de relevante øvrighedspersoner. Dertil anvender de deres ædelmodige gæstfrihed og deres giftefærdige døtre, den første har de allerede fảet afsat til en passende fornem 'kjæltring', og den næste, Gjatrid, er på vej til den korrupte herredsfuldmægtig. Kærligheden kan dog alligevel lægge sig imellem: Gjatrid forelsker sig i Anders, og hendes bror i hans søster, da hun er kommet til som hans husholderske. Men retfærdigheden kommer Anders derfor ingen vegne med. Der er ikke noget stille op mod det netværk, som ejerne på Staun har spundet omkring sig, herredsfuldmægtigen strækker sig endog ud over sin umorals grænser i håbet om at Gjatrid til sidst vil blive tvunget til at tage ham. Anders raser og kæmper hinsides al fornuft, han véd ikke selv hvorfor, men han kan ikke leve med at uretfærdigheden skal sejre, det må så koste hvad det koste vil, også hans kæreste. Og selv med den viden om ham går der ingen skår i hendes kærlighed, og han-beshutter sig-endelig til-egrenhæændigt at ove retfærdighed. Og så jo til at fri sin Gjatrid fra skurkens truende kløer.

Da beslutningen er truffet, falder der ro over Anders Hjarmsted. Han morer sig nu over faderens fortsatte fablen om retslige udveje. Han forbereder sig sindigt til han fornemmer $\mathrm{i}$ sig, at dagen og timen er inde. Han går da en sen aften op til herredsfuldmægtigen med en hammer $\mathrm{i}$ hånden, han hamrer den to gange $\mathrm{i}$ skallen på ham, henter sin kæreste, tvinger ved midnatstid præsten til at vie dem, og de løber under høj latter, jublende af glæde, ud over heden, fejrer deres bryllupsnat, og næste morgen er Anders tilbage med hammeren, for fuldmægtigen havde en hjælper, arrestforvalteren, som han ikke aftenen før fik det gjort af med. Det gør han så nu, på den første og den sidste dag $\mathrm{i}$ sit nye liv, så lykkelig og så blodigt knuser han hans hoved. Kort efter bliver han skudt ned.

Det er den jyske betydning af 'at have sind' der således har manifesteret sig: den vilde og heftige kom- 
promisløshed. Jakob Knudsen blæste genialt på alle gængse degneforestillinger om danskeren som et udpræget tamdyr eller om en særlig snu sagtmodighed i det bondske gemyt. Den danske bonde Anders Hjarmsted, der flytter fra Han Herred til Himmerland, kunne lige så godt have været en kosakisk immigrant i Australien, han er simpelt hen et menneske der i krænket retsfølelse kræver rettens absolutte sejr, en idealist $i$ selvsving. $O g$ sådan her vil det altså gå ham $\mathrm{i}$ et korrupt samfund, der vel at mærke heller ikke råder over tilstrækkelig åndskraft til at lede hans idealitet på andre veje (romanens sognepræst er et gudsjammerligt skvat).

Hele splattertragedien er fuldt overbevisende udfoldet, og det kan der naturligvis anføres kunstneriske årsager til: en logisk konfliktopbygning, en anskueliggjort indsigt i sjælelige forløb, en tankemæssig konsistens, frem for alt en sproglig-artistisk formåen over et stort register. Skulle man begrunde hvad der herudover, og egentlig, løfter Sind op blandt de bedste fortællinger $\mathrm{i}$ vores litteratur, ville jeg mene at den måske mere end nogen anden gør dette sind virkeligt $\mathrm{i}$ sproget. $\mathrm{Og}$ da meget mere end sindet $\mathrm{i}$ nævnte jyske forstand, snarere menneskesindet i hele dets halvbevidste, plasmaagtige almenhed, og den virkeliggør det altså ikke alene ved at vise det $\mathrm{i}$ voldsomt udbrud, men på sin vis meget stærkere end det - og allerede længe før det sker - ved gang på gang at søge en præcision af forskelligartede sindstilstande i deres endnu svævende uafgjorthed.

Anders Hjarmsted slipper ved mere end én lejlighed ind $i$ sådan nogle mentale rum, med en uendelig blå himmel over, hvor han ville have kunnet fæste bo, og hvorfra han ville have kunnet færdes blandt andre mennesker, så fri og værgeløs som dem. Men noget er jo knækket i ham engang, i den nådesløst gudfaderlige barndom, og det er derpå vokset så stift og knoklet sammen igen, at han nu ikke kan tro om livet, at det så generøst vil tilbyde ham noget godt. Noget langt bedre end hvad han selv har kunnet udtænke og sætte sin rasende vilje ind på at gennemtrumfe over for alt og alle. 